\title{
Wystawa plenerowa „650 lat herbu miasta Krakowa” dedykowana Profesorowi Marianowi Friedbergowi w 50. rocznicę śmierci
}

W marcu 2019 r. minęła 50. rocznica śmierci prof. Mariana Friedberga (1902-1969), wybitnego historyka i archiwisty, wieloletniego dyrektora Archiwum Państwowego w Krakowie (1939-1952). Jednym z ważnych osiągnięć Profesora było naukowe opracowanie dziejów herbu Krakowa ${ }^{1}$ - stało się ono podstawą do starań o jego urzędowe zatwierdzenie. Choć z powodu wybuchu wojny urzędowe przyjęcie herbu nie doszło do skutku, to jednak projekt zamieszczony w rozprawie $M$. Friedberga był przez 65 lat faktycznym herbem miasta, do czasu jego nowoczesnego opracowania i oficjalnego zatwierdzenia w $2002 \mathrm{r}$.

Archiwum Narodowe w Krakowie, chcąc uhonorować osobę prof. M. Friedberga, a jednocześnie ukazać dzieje i znaczenie herbu Krakowa, przygotowało we współpracy z Towarzystwem Miłośników Historii i Zabytków Krakowa oraz Urzędem Miasta Krakowa plenerową wystawę poświęconą dziejom herbu Krakowa. Zaprezentowana została najpierw na placu Szczepańskim w Krakowie (w dniach 8-29 października 2019 r.), a następnie na dziedzińcu budynku Archiwum Narodowego w Krakowie przy ul. Siennej 16 (od 29 października do 2 grudnia 2019 r.). Honorowy patronat nad wystawą objął Prezydent Miasta Krakowa Jacek Majchrowski, który przemówił - obok przedstawicieli organizatorów, na jej uroczystym otwarciu na placu Szczepańskim w Krakowie w dniu 10 października 2019 r., o godzinie 12.00.

Inicjatorem i pomysłodawcą ekspozycji był dr hab. prof. UJ Zenon Piech, kierownik Zakładu Nauk Pomocniczych Historii Uniwersytetu Jagiellońskiego, był on również autorem scenariusza i, wraz z Bożeną Lesiak-Przybył i Aldoną Warzechą, współautorem koncepcji merytorycznej. Projekt graficzny ekspozycji opracowała dr hab. prof. ASP Barbara Widłak z Katedry Komunikacji Wizualnej Akademii Sztuk Pięknych im. Jana Matejki w Krakowie.

Herb Krakowa jest głównym znakiem miasta od trzeciej ćwierci XIV w. Wprowadzony w czasach Kazimierza Wielkiego, przez 650 lat współistniał z miastem, stopniowo utrwalał się, ale ulegał też przemianom. Autorzy chcieli zaprezentować zarówno dzieje herbu Krakowa (od średniowiecza do współczesności), jak również ukazać niezliczone sfery jego występowania jako znaku prawnego i dzieła sztuki.

Przeprowadzona kwerenda potwierdziła obecność herbu niemal we wszystkich obszarach aktywności miasta i jego mieszkańców, jednak konieczne było znaczne ograniczenie zebranego materiału i dokonanie wyboru głównych zagadnień ilustrujących jego dzieje i funkcje ${ }^{2}$. Względy techniczne (eksponowanie materiałów w formie wystawy posterowej)

\footnotetext{
${ }^{1}$ Marian Friedberg, Herb miasta Krakowa, „Rocznik Krakowski” 1937, t. 28, s. 97-138.

${ }^{2}$ Założenia, przebieg i szczegółowe omówienie wyników kwerendy zob. Bożena Lesiak-Przybył, Aldona Warzecha, Herb Krakowa w zbiorach Archiwum Narodowego w Krakowie, [w:] 650 lat herbu miasta Krakowa. Katalog wystawy, Kraków 2019, s. 23-26.
} 
wymuszały bowiem dostosowanie zakresu i rozmiarów ekspozycji do tej formy prezentacji. Wystawa została oparta w zasadniczej większości na materiałach archiwalnych z zasobu Archiwum Narodowego w Krakowie. W celu dopełnienia przekazu, w niektórych przypadkach, narrację urozmaiciły wizerunki eksponatów i muzealiów pochodzących ze zbiorów innych instytucji: Archiwum Głównego Akt Dawnych, Archiwum Uniwersytetu Jagiellońskiego, Bazyliki Mariackiej w Krakowie, Biblioteki Jagiellońskiej, Kościoła pw. św. Wojciecha w Krakowie, Muzeum Krakowa, Muzeum Narodowego w Krakowie, Muzeum Uniwersytetu Jagiellońskiego, Urzędu Miasta Krakowa, Zamku Królewskiego w Warszawie. Obiekty te zajmowały na wystawie wyjątkową pozycję, wspaniale ją wzbogacając.

Ostatecznie na $26^{3}$ planszach zaprezentowane zostały obiekty ilustrujące dzieje herbu Krakowa oraz bogactwo i zróżnicowanie dziedzin życia notujących jego obecność. Każda plansza zawierała tytuł sygnalizujący jej tematykę, tekst zasadniczy opracowany w konwencji popularnonaukowej oraz ilustracje obiektów wraz z rozbudowanymi podpisami. Łącznie na wystawie pokazano 190 obiektów, których różnorodność była ogromna ${ }^{4}$.

Trzy pierwsze plansze: „Herb znak miasta”, „Na początku była pieczęć”, „Geneza herbu" stanowiły niejako wprowadzenie do tematu. Najstarszym zachowanym zabytkiem przedstawiającym herb Krakowa jest dzwon z kościoła Mariackiego, datowany na czwartą ćwierć XIV w. Natomiast od XV w., obok pieczęci miejskich, herb pojawiał się coraz częściej na różnych zabytkach związanych z miastem. Wybrane starodruki, zebrane na tablicy „Blask renesansowych druków”, dowodziły, że od XVI w. działały w Krakowie liczne oficyny wydawnicze używające jako elementu identyfikacji sygnetów drukarskich, na których, obok herbów państwowych Orła i Pogoni, ważne miejsce zajmował herb Krakowa oraz znak konkretnego drukarza. Dalsze przemiany herbu Krakowa, aż do wersji znanej obecnie, kształtowały się przez dłuższy czas. Na planszy „Lata zmian” zasygnalizowany został ów proces, trwający od czwartej ćwierci XVI w. aż do 1661 r., a mający na celu udostojnienie herbu królewskiego miasta. Od średniowiecza jednym z najważniejszych miejsc w przestrzeni miasta był ratusz, siedziba władz, tam mieściły się kancelaria i archiwum miejskie, tam przechowywano tłoki pieczętne oraz księgi miejskie i dokumenty. Z tą szeroką obecnością herbu w rozlicznych obszarach aktywności miasta można było zapoznać się na kilku kolejnych planszach („Ratusz - siedziba władz miejskich”, „Dokumenty miejskie”, „Oprawy ksiąg miejskich i superekslibrisy”, „Ilustracje w księgach miejskich”, „Chorągiew Krakowa”, „Budynek Magistratu”). Wprawdzie głównym obszarem manifestacji herbu Krakowa była sfera świecka, jednak mocny wpływ religii na życie mieszkańców miasta i jego władz prowadził do obecności herbu także w przestrzeni sakralnej, co ilustrowała tablica „W sferze sakralnej”. Natomiast związek miasta z Uniwersytetem Jagiellońskim, znajdujący odzwierciedlenie także w symbolice heraldycznej (co przejawiało się współwystępowaniem obydwu herbów - miasta i Uniwersytetu - zarówno na pieczęciach poszczególnych wydziałów, jak i na zachowanych zabytkach uniwersyteckich) ilustrowała plansza

${ }^{3} \mathrm{Na}$ wystawę złożyło się 28 plansz, z czego dwie - tytułowa i końcowa, miały charakter wyłącznie informacyjny (tytuł wystawy, dane organizatorów i partnerów itp.). Zawartość merytoryczna ekspozycji była prezentowana na pozostałych 26 tablicach.

${ }^{4} \mathrm{~W}$ tym: dokumenty, księgi, tłoki pieczętne i pieczęcie, rysunki, grafiki, fotografie, dyplomy, zaproszenia, kalendarze, afisze i bilety teatralne oraz inne druki okolicznościowe, mapy, plany, starodruki i książki oraz muzealia. 
„W przestrzeni Uniwersytetu Jagiellońskiego”. Inne obszary występowania herbu Krakowa ukazane zostały na tablicach „Wśród herbów państwa”, „Widoki i plany Krakowa”, „W symbolice cechowej” „W życiu codziennym XIX-XX wieku”. Dalsze przemiany herbu Krakowa w ujęciu chronologicznym można było z kolei prześledzić na planszach: „Herb miasta herbem państwa” (okres Wolnego Miasta Krakowa), „W autonomicznym Krakowie”, „Odzyskiwanie wolności”, „W drodze do zatwierdzenia”, „Pod okupacją niemiecką”, „W czasach PRL”, aż po czasy współczesne (tablice „Współczesne insygnia władz miasta” i „Znaki miasta dziś”). Zebrany materiał potwierdził, że w zasadzie niezależnie od okresu historycznego - herb miasta odgrywał ogromną rolę w przekazie propagandowym każdej epoki i był wykorzystywany niemal we wszystkich dziedzinach życia miasta i społeczeństwa. Ostatnia plansza - „Herb Krakowa w badaniach naukowych” stanowiła uhonorowanie trzech wybitnych historyków - badaczy herbu Krakowa - prof. M. Friedberga, Adama Chmiela (1865-1934) i doc. Włodzimierza Budki (1894-1977).

Wszystkie materiały zgromadzone na wystawie, w układzie zaprezentowanym na planszach, udało się zebrać w katalogu wystawy ${ }^{5}$, który ukazał się drukiem już w listopadzie 2019 r. i został wydany nakładem Archiwum Narodowego w Krakowie. Premierę publikacji połączono z uroczystym zamknięciem wystawy, które odbyło się w dniu 30 listopada 2019 r. w siedzibie Archiwum przy ul. Siennej 16. Dr hab. prof. UJ Z. Piech uświetnił finisaż swoim wykładem pt. „Herb Krakowa - klejnot dziedzictwa historycznego miasta” oraz oprowadzeniem zebranych po ekspozycji.

Pragniemy podziękować wymienionym wyżej instytucjom, dzięki którym nasza ekspozycja była atrakcyjniejsza, Panu Bogdanowi Kasprzykowi z Urzędu Miasta Krakowa za nieocenione wsparcie oraz Koleżankom i Kolegom z Archiwum za udzieloną pomoc.

Bożena Lesiak-Przybyt, Aldona Warzecha Archiwum Narodowe w Krakowie

${ }^{5} 650$ lat herbu miasta Krakowa. Katalog... 